\title{
Pandemi dan Bentuk Diskriminasi Baru: Sebuah Kritik Terhadap Perilaku Masyarakat Dalam Menghadapi Wabah Covid-19
}

\author{
Arif Widodo \\ Program Studi PGSD, FKIP Universitas Mataram \\ arifwidodo@unram.ac.id
}

\begin{abstract}
ABSTRAK
Aspek sosial merupakan salah satu bidang yang paling banyak terdampak dengan adanya wabah Covid-19. Selain menjaga kebersihan, melakukan pembatasan sosial merupakan langkah yang dianggap paling efektif agar tidak terjangkit Covid-19. Respon masyarakat dalam bidang sosial telah menimbulkan fenomena baru yaitu munculnya diskriminasi. Penelitian ini bertujuan mengungkap penyebab dan bentuk-bentuk diskriminasi selama wabah Covid-19. Penelitian ini menggunakan pendekatan fenomenologi. Pendekatan ini digunakan untuk memahami dan menggambarkan secara detail terkait dengan fenomena yang terjadi di masyarakat selama pandemi. Pengumpulan data melalui wawancara dan observasi partisipasi. Lokasi penelitian di kota Mataram. Masalah yang akan dikaji dalam penelitian ini antara lain: Mengapa diskriminasi itu terjadi? Bagaimana bentuk diskriminasi yang ada di dalam masyarakat selama pandemi? Hasil penelitian menunjukkan bahwa perilaku diskriminasi terjadi karena adanya ketakutan yang berlebihan dalam menanggapi Covid-19. Bentuk diskriminasi barau yang muncul di era pandemi antara lain diskriminasi kebijakan, diskriminasi peribadahan dan diskriminasi sosial. Diskriminasi kebijakan dapat terlihat dari adanya perbedaan perlakuan dan peraturan terhadap bidangbidang yang berpotensi menjadi tempat penyebaran wabah. Diskriminasi peribadahan terlihat dari adanya pembatasan penggunaan tempat ibadah bagi masyarakat di luar komunitas. Diskriminasi sosial diwujudkan dengan adanya sikap saling mencurigai, pengucilan terhadap para perantau, pengucilan terhadap orang yang sakit, enggan membantu orang yang sakit, pengucilan terhadap orang yang terindikasi Covid, antipati terhadap orang asing dan terbentuknya lingkungan inklusif. Bentuk-bentuk diskriminasi baru tersebut kontradiktif dengan karakter asli bangsa Indonesia yang ramah, kekeluargaan, menjunjung tinggi nilai-nilai keadilan dan saling membantu jika saudara mengalami kesusahan. Covid-19 telah membentuk mental yang cenderung mencari hidup sendiri tanpa peduli orang lain.
\end{abstract}

Kata Kunci: diskriminasi baru, kritik sosial, perilaku masyarakat, wabah covid-19

\begin{abstract}
The social aspect is one of the areas most affected by the Covid-19 outbreak. In addition to maintaining cleanliness, social restrictions are considered the most effective steps to avoid contracting Covid-19. Community response in the social field has given rise to a new phenomenon, namely the emergence of discrimination. This study aims to reveal the causes and forms of discrimination during the Covid-19 outbreak. This research uses a phenomenological approach. This approach is used to understand and describe in detail related to phenomena that occur in society during a pandemic. Data collection through interviews and participatory observation. Research location in the city of Mataram. The issues to be examined in this study include: Why did discrimination occur? What forms of discrimination existed in the community during the pandemic? The results showed that discriminatory behavior occurs because of excessive fear in responding to Covid-19. New forms of discrimination that emerged in the pandemic era included policy discrimination, worship discrimination, and social discrimination. Policy discrimination can be seen from the different treatments and regulations in areas that have the potential to become epidemics. Discrimination in worship can be seen from the restrictions on the use of places of worship for people outside the community. Social discrimination is manifested by mutual suspicion, isolation of migrants, isolation of sick people, reluctance to help sick people, isolation of people who are indicated by COVID, antipathy towards strangers, and the creation of an inclusive environment. These new forms of discrimination are contradictory to the genuine character of the Indonesian people who are friendly, family, uphold the values of justice, and help each other if you experience difficulties. Covid-19 has formed a mind that tends to look for life alone without caring about others.
\end{abstract}

Keywords: new discrimination, social criticism, community behavior, covid-19 outbreak

PENDAHULUAN 
Penelitian ini diawali atas keprihatinan terhadap reaksi masyarakat dalam menghadapi covid-19. Berdasarkan hasil sebuah penelitian Covid-19 memang memiliki tingkat penyebaran yang sangat cepat. Dengan tingkat penyebaran yang sangat tinggi membuat masyarakat dunia mengalami kepanikan (Depoux, Martin, Karafillakis, Preet, \& WilderSmith, 2020). Menurut laporan yang dirilis oleh WHO dapat diketahui bahwa sebagia besar Negara dunia saat ini telah terpapar virus yang dianggap sangat mematikan ini (Lippi \& Plebani, 2020). Dibutuhkan kesadaran dan perubahan perilaku sosial yang besar dalam menanggapi wabah Covid-19 (Bavel et al., 2020). Salah satunya dengan mengadakan pembatasan sosial berskala besar. Hal ini dikarenakan dalam menghambat penyebaran virus cara yang dianggap paling efektif adalah dengan menjaga jarak sosial (Andersen, 2020). Aktivitas masyarakat harus dikontrol. Patroli keamanan serta pemberlakuan jam malam dalam hal ini perlu dilakukan (Marston, Musselwhite, \& Hadley, 2020). Selain itu tindakan preventif dengan mengisolasi dan menjemput paksa orang yang diduga terpapar virus Corona sangat diperlukan (Watkins, 2020). Kondisi semacam ini menimbulkan reaksi yang berlebihan di dalam masyarakat. Salah satunya menimbulkan sikap diskriminasi.

Tindakan diskriminasi yang terjadi selama pandemi Covid-19 telah mengguncang tatanan sosial di masyarakat. Sebelum terjadinya pandemi masyarakat dapat hidup berdampingan tanpa adanya diskriminasi. Masyarakat dapat hidup rukun, kerjasama dan penuh toleransi (Widodo, 2020a). Tidak ada pembedaan dalam berinteraksi. Semua golongan masyarakat mendapatkan perlakuan yang sama. Namun dengan adanya wabah sikap curiga satu sama lain mulai terlihat. Hal ini sangat kontradiktif dengan karakter bangsa Indonesia yang selalu menjunjung tinggi nilai-nilai kemanusiaan. Dengan adanya pandemic tatanan sosial mengalami perubahan. Terdapat sebuah penelitian yang menyebutkan bahwa diskriminasi dapat menyebabkan dampak yang sangat buruk dalam bidang sosial (Kantamneni, 2020). Maka dari itu penghargaan terhadap nilai-nilai kemanusiaan dan martabat setiap individu harus dijunjung tinggi (Bledsoe, Jokela, Deep, \& Snyder Sulmasy, 2020). Setiap individu seharusnya mendapat perlakuan yang sama. Sikap diskriminasi dapat menimbulkan stress dan meninggalkan trauma yang mendalam bagi orang-orang yang mengalaminya (Bo et al., 2020). Hal ini dikarenakan tindakan diskriminasi merupakan salah satu bentuk perampasan terhadap kemerdekaan (Indraswati, Widodo, Rahmatih, Maulyda, \& Erfan, 2020).

Terdapat beberapa penelitian terdahulu yang membahas tentang diskriminasi selama pandemi. Penelitian (Chung- Ying, 2020) menyebutkan bahwa telah terjadi diskriminasi ras di beberapa Negara asia selama pandemic Covid-19. Dalam penelitian tersebut diungkapkan masing-masing ras mengalami ketakutan jika berinteraksi terhadap orang lain yang berasal dari ras berbeda. Hal ini merupakan salah satu bentuk reaksi sosial masyarakat dalam menanggapi pandemi. Pada penelitian lain disebutkan bahwa etnis yang paling banyak menerima sikap rasis dan diskriminasi adalah etnis China (Devakumar, Shannon, Bhopal, \& Abubakar, 2020). Hal ini dikarenakan munculnya virus Corona pertama kali menyebar di China, sehingga setiap orang China dianggap sebagai penyebar virus dan harus dihindari. Penelitian serupa juga menyatakan bahwa diskriminasi terhadap orang-orang China terjadi di mana-mana (He, He, Zhou, Nie, \& He, 2020). Dalam penelitian tersebut diungkapkan bahwa pengucilan terhadap etnis China telah menimbulkan kerugian yang lebih besar. Bahkan dalam penelitian lain disebutkan bahwa pelajar China di luar negeri menghadapi diskriminasi dan isolasi di beberapa negara karena dianggap berpotensi menjadi pembawa virus (Zhai \& Du, 2020). Mereka hidup dalam ketakutan dan dianggap paling bertanggung jawab dalam penyebaran COVID-19. Pada penelitian lain juga diungkap adanya diskriminasi selama wabah Covid-19 di Negara terdampak virus. Namun diskriminasi yang terjadi tidak terkait dengan diskriminasi ras tetapi berkaitan dengan penyediaan layanan kesehatan di garis depan 
(Singh \& Subedi, 2020). Diskriminasi ini terjadi karena jumlah kasus meningkat, sedangkan jumlah penyedia layanan kesehatan terbatas. Hanya orang-orang tertentu yang dapat menikmati layanan kesehatan.

Berdasarkan uraian latar belakang di atas perlu dilakukan penelitian serupa yang berkaitan dengan diskriminasi di era pandemi di Indonesia, khususnya di kota Mataram. Kota ini menjadi lokasi penelitian karena merupakan salah satu wilayah yang terdampak virus Corona. Berdasarkan observasi awal indikasi adanya diskriminasi di daerah ini juga terlihat. Maka dari itulah pentingnya diadakan penelitian ini. Penelitian ini bertujuan untuk menganalisis fenomena terjadinya diskriminasi sosial di lingkungan masyarakat. Masalah utama yang akan di kaji dalam penelitian ini antara lain bagaimana persepsi masyarakat tentang Covid-19 sehingga menimbulkan diskriminasi? Bagaimana bentuk diskriminasi yang terjadi di lingkungan masyarakat? Melalui penelitian ini diharapkan dapat menghasilkan pengetahuan yang bermanfaat sehingga diskriminasi di dalam masyarakat tidak terjadi lagi.

\section{METODE}

Penelitian ini menggunakan pendekatan fenomenologi. Melalui penelitian ini peneliti akan mengungkap realitas yang tampak dan realitas yang tidak tampak di dalam masyarakat. Terutama munculnya diskriminasi akbibat adanya Covid-19. Pengambilan data di kota Mataram dan sekitarnya. Pengumpulan data menggunakan observasi dan wawancara. Informan dalam penelitian ini adalah tokoh agama, tokoh masyarakat dan masyarakat pada umumnya. Penentuan sampel menggunakan metode snowball sampling. Pengambilan data dihentikan setelah pengumpulan data mencapai titik jenuh. Pengujian keabsahan data menggunakan teknik triangulasi sumber. Komparasi data dari informan satu dengan informan lain dilakukan agar data yang didapatkan teruji kebenarannya. Hal ini dilakukan untuk mengungkap relaitas yang tidak tampak dalam sebuah fenomena.

\section{HASIL DAN PEMBAHASAN}

\section{Perilaku Masyarakat di Era Pandemi}

Pandemic Covid-19 menimbulkan reaksi yang beragam di dalam masyarakat. Banyak masyarakat yang menanggapi dengan santai, tetapi tidak sedikit pula yang menanggapi dengan serius. Perbedaan persepsi dalam menanggapi wabah Covid-19 berpengruh terhadap bentuk perilaku masyarakat. Bagi masyarakat yang mempunyai persepsi bahwa Covid-19 sama halnya dengan jenis penyakit lainnya maka mereka cenderung abai. Himbauan Pemerintah untuk selalu mematuhi protocol Covid-19 dalam setiap aktvitas cenderung tidak dipatuhi. Pemerintah terus menghimbau masyarakat agar selalu memakai masker, menjaga jarak, dan selalu menjaga kesehatan dengan cara mencuci tangan dengan sabun. Berdasarkan hasil pengamatan terhadap perilaku masyarakat tidak banyak masyarakat yang mau menggunakan masker. Bahkan Polisi dan instansi terkait sering melakukan razia masker di jalan-jalan besar untuk meningkatkan kesadaran masyarakat dalam menggunakan masker. Tidak hanya di jalan-jalan polisi juga sering melakukan razia di pasar dan pusat perbelanjaan lainnya. Hal ini dilakukan mengingat kesadaran masyarakat dalam menggunakan masker masih rendah. Di sisi yang lain terdapat sekelompok orang yang memanfaatkan pandemic sebagai ladang bisnis. Salah satunya adalah monopoli barang dagangan yang dibutuhkan di tengah pandemi seperti masker dan handsanitizer. Implikasinya sebagian orang memilih untuk tidak membeli barang-barang tersebut karena harganya melambung tinggi.

Kesadaran masyarakat dalam menjaga kebersihan juga masih kurang. Berdasarkan hasil pengamatan terlihat bahwa masyarakat cenderung mengabaikan fasilitas cuci tangan yang disediakan oleh tempat ibadah. Berdasarkan hasil wawancara terhadap salah satu jamaah dapat diketahui bahwa mereka tidak mau cuci tangan sesuai dengan protocol Covid- 
19 dengan alasan bahwa mencuci tangan dengan berwudhu lebih baik dari pada hanya mencuci tangan saja dengan sabun. Lebih lanjut dikatakan bahwa dengan berwudhu tidak hanya tangan saja yang dicuci tetapi juga muka sampai dengan kaki. Hal ini dianggap lebih bersih dari pada hanya mencuci tangan saja. Jamaah lain ketika diwawancarai mengatakan bahwa tempat ibadah khususnya Masjid dan Musholla adalah tempat yang paling suci. Hal ini dikarenakan setiap orang yang akan masuk ke tempat ibadah tersebut telah bersuci. Hal ini tidak terlepas dari ajaran Islam bahwa kebersihan adalah sebagian dari pada iman. Maka dari itu dapat dipastikan setiap tempat ibadah umat Islam selalu menyediakan tempat wudhu. Dengan kondisi seperti ini seharusnya menyediakan tempat cuci tangan sesuai dengan protocol Covid di tempat ibdah terasa aneh. Menurut penuturan salah satu jamaah "Kalaupun harus mencuci tangan dengan sabun sebaiknya cukup disediakan sabun di tempat wudhu, tidak harus memasang tong air yang hanya berkapasitas kecil di tempat ibadah".

Perilaku masyarakat dalam menjaga kebersihan salah satunya dipengaruhi oleh ketersediaan fasilitas cuci tangan. Tempat ibadah sejatinya telah ada tempat bersucinya justru disediakan tempat cuci tangan, sedangkan pasar yang merupakan tempat berkumpulnya masyarakat tidak disediakan. Hal ini sangat kontradiktif dengan himbauan pemerintah agar selalu menjaga kebersihan supaya tidak terjadi penularan virus. Jika diamati pasar memiliki potensi penularan virus lebih besar dari pada di tempat ibadah. Hal ini dikarenakan sebersih apapun pasar keberadaan kuman penyakit lebih besar jika dibandingkan dengan di tempat ibadah. Lalu lintas barang dagangan dari luar daerah maupun luar negeri memperbesar peluang penularan virus. Selain itu durasi aktivitas lebih lama jika dibandingkan dengan di tempat ibadah. Proses jual beli dan tawar menawar barang dagangan tidak menutup kemungkinan terjadinya penularan. Terlebih lagi di pasar tradisional yang pengunjungnya cenderung tidak teratur, berjubel dan lalu lintas pengunjung tidak ada pembatasan. Melihat fenomena ini masyarakat berpendapat seharusnya fasilitas cuci tangan juga disediakan di pasar, terutama pasar tradisional. Berdasarkan hasil pengamatan di beberapa pasar tradisional di kota Mataram dan sekitarnya tidak ada fasilitas cuci tangan yang disediakan untuk pengunjung. Kalaupun ada ember yang berisi air dan sabun bisanya disediakan oleh toko kelontong secara mandiri. Kapasitas air yang disediakanpun tidak mencukupi untuk semua pengunjung, sehingga seringkali dijumpai ember yang telah kosong. Menurut salah satu pemilik toko kelontong terungkap bahwa yang terpenting telah disediakan tempat cuci tangan, apabila ada petugas yang keliling supaya tidak dimarahi. Walaupun kecil yang penting telah tersedia karena tidak semua pengunjung mau cuci tangan meskipun telah disediakan.

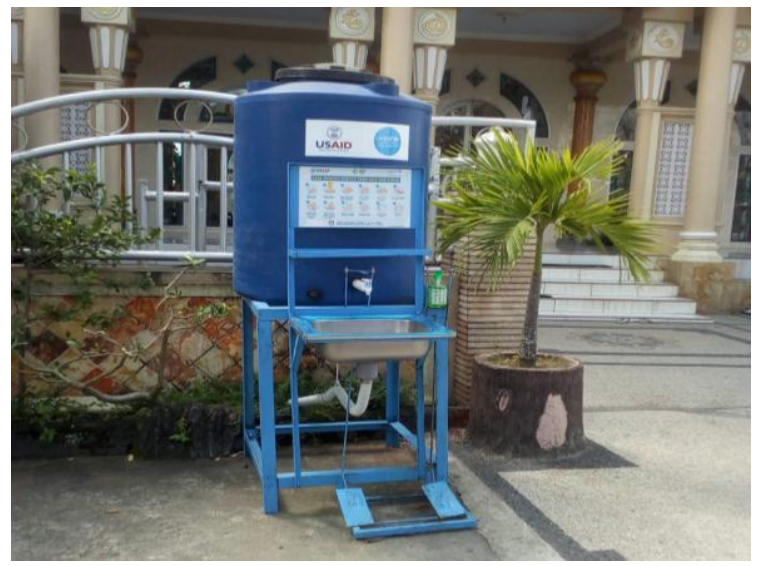

Gambar 1. Fasilitas cuci tangan di tempat ibadah.

Gambar 1 merupakan fasilitas cuci tangan yang terdapat pada salah satu tempat ibadah. Berdasarkan pengamatan terhadap gambar di atas dapat terlihat bahwa fasilitas 
tersebut jarang digunakan. Hal ini dapat terlihat dengan tidak adanya bekas air di bawah penampungan air tersebut. Padahal fasilitas tersebut tidak ada saluran khusus untuk pembuangan ke saluran air. Jika fasilitas cuci tangan tersebut sering digunakan pasti akan terlihat basah di sekitar tempat tersebut. Melihat fenomena ini dapat dipahami bahwa menyediakan tempat cuci tangan di tempat ibadah kurang efektif. Hal ini dikarenakan di tempat ibadah telah disediakan tempat wudhu. Jika diamati lebih mendalam melakukan wudhu lebih bersih dari pada sekedar cuci tangan. Maka dari itu fasilitas cuci tangan yang sesuai standar Covid sebaiknya disediakan di tempat berkumpulnya massa yang lebih banyak, salah satunya adalah pasar tradisional. Hal ini ironis mengingat pasar yang banyak mengandung kotoran dan kuman tidak disediakan tempat cuci tangan, sedangkan masjid yang telah ada tempat wudhunya justru disediakan. Fenomena ini membuat masyarakat semakin bertanya-tanya, seakan-akan tempat penyebaran virus berada di tempat ibadah.

\section{Pandemic dan diskriminasi}

Tidak semua masyarakat menganggap remeh dengan pandemic Covid-19. Banyak juga masyarakat yang menanggapi pandemic ini dengan sangat serius. Masyarakat yang tergabung dalam kelompok ini cenderung melakukan hal-hal yang berlebihan dalam menghadapi pandemi. Salah satu dampaknya adalah munculnya sikap diskriminasi di dalam masyarakat. Berdasarkan hasil wawancara terhadap beberapa warga masyarakat dapat diketahui bahwa pandemic ini menimbulkan ketakutan yang luar biasa di dalam masyarakat. Terlebih lagi dengan pemberitaan di media massa yang semakin gencar membuat masyarakat semakin was-was. Implikasinya terjadi sikap over ptotective. Tujuannya adalah agar tidak tertular virus Corona. Namun di sisi lain sikap over protective ini justru menimbulkan dampak yang kurang baik di dalam masyarakat. Sikap ini telah menimbulkan bentuk diskriminasi baru di dalam masyarakat. Hubungan sosial yang telah terjalin sejak lama dapat terkikis akibat adanya pandemic. Satu sama lain saling mencurigai. Bahkan jika ada tetangga yang bersin atau batuk tidak jarang membuat orang sekitarnya menjauh.

Pandemic tidak hanya menimbulkan diskriminasi tetapi juga menimbulkan keretakan hubungan persaudaraan. Hubungan persaudaraan dapat renggang akibat adanya sikap enggan dalam menolong saudara yang terindikasi Covid. Setiap orang berusaha mencari hidupnya sendiri. Salah satu warga menceritakan pengalamannya terkait dengan masalah ini yang dihadapi beberapa waktu yang lalu. Pada saat itu orang tuanya mengalami sesak nafas, sakit kepala dan suhu badannya tinggi. Kemudian dia berinisiatif untuk meminjam kendaraan kepada salah seorang kerabatnya. Namun yang terjadi saudaranya tersebut tidak mau memberi pinjaman kendaraan. Dengan melihat gejala yang dimiliki ada indikasi telah terpapar covid. Hal inilah yang menyebabkan saudaranya tidak mau memberi pinjaman, karena takut tertular. Perilaku semacam ini telah menjadi hal yang biasa terjadi di kalangan masyarakat. Sebagian besar diantara mereka tidak mau berpikir panjang jika ada diantara mereka yang mengalami sakit. Rata-rata mereka langsung melakukan vonis Covid. Dengan adanya pandemic ini orang yang sakit bukan diberi bantuan tetapi yang mereka terima adalah diskriminasi.

\section{Bentuk Diskriminasi di Era Pandemi}

Pandemic telah melahirkan berbagai macam bentuk diskriminasi baru. Diskriminasi kebijakan termasuk salah satu diantaranya. Kebijakan yang dibuat pemerintah terkesan kontradiktif dengan semangat perang melawan Corona terutama yang berkaitan dengan menjaga jarak sosial. Pembatasan hanya dilakukan pada aspek tertentu, sedangkan pada aspek yang lain di buka lebar. Salah satu bidang yang mendapatkan pembatasan ketat adalah dalam bidang ritual keagamaan. Adanya perbedaan kebijakan dalam setiap bidang membuat masyarakat merasa kebingungan. Kondisi semacam ini menimbulkan berbagai polemik di 
masyarakat. Sungguh ironis, mengingat tempat ibadah merupakan tempat yang suci dan intensitas peribadahanpun dalam waktu yang relatif pendek. Sedangkan pasar sebagai pusat aktivitas sosial dan ekonomi yang memiliki tingkat mobilitas tinggi tidak dilakukan pembatasan. Hal inilah yang disebut dengan diskriminasi kebijakan. Jika yang menjadi permasalahan adalah kerumunan massa, seharusnya pasar lebih berkerumun dari pada tempat ibadah. Orang yang datang beribadah pasti telah bersuci, namun orang yang ada dipasar belum terjamin kebersihannya. Terlebih lagi bergumul dengan barang dagangan yang beraneka warna membuat pasar jauh dari kata suci. Orang yang beribadah dibatasi, sedangkan orang yang ke pasar tidak dibatasi. Seharusnya jika ingin penyebaran benar-benar putus semua bidang harus diberlakukan kebijakan yang sama. Termasuk dalam hal ini adalah pasar. Pasar harus diawasi secara ketat dan fasilitas kesehatan sesuai standar Covid harus disediakan. Tidak ada gunanya membatasi diri untuk tidak datang ke tempat ibadah tetapi masih berinteraksi dengan orang banyak di pasar. Hal ini dikarenakan potensi penyebaran dan penularan virus di pasar lebih besar dari pada di tempat ibadah.

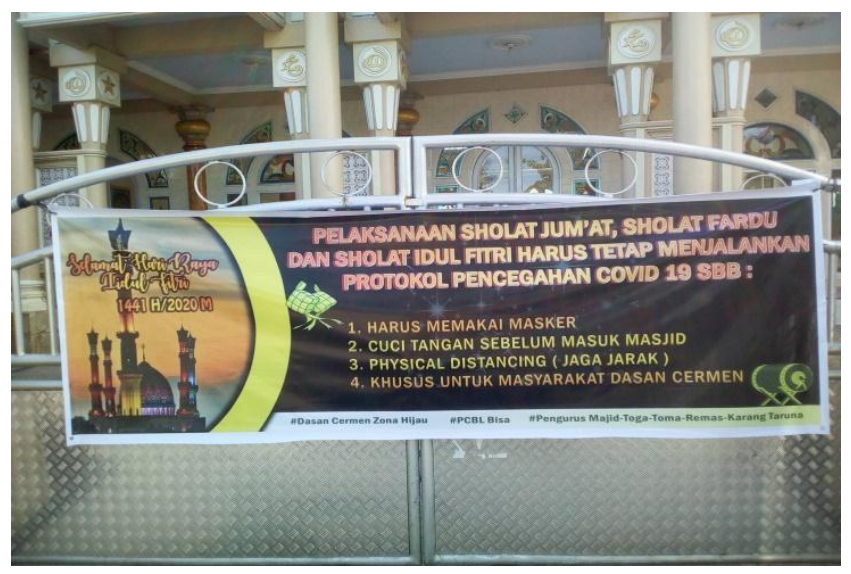

Gambar 2. Bentuk diskriminasi dalam beribadah.

Diskriminasi kebijakan memiliki dampak terhadap lahirnya bentuk deskriminasi lain. Salah satunya adalah bentuk diskriminasi dalam beribadah. Berdasarkan hasil pengamatan terhadap beberapa tempat ibadah terllihat adanya pembatasan penggunaan tempat ibadah bagi masyarakat di luar komunitas. Tempat ibadah hanya digunakan oleh golongan tertentu. Hal ini menunjukkan adanya diskriminasi dalam beribadah. Berdasarkan gambar 2 sangat jelas tertulis adanya diskriminasi terhadap penggunaan sarana ibadah. Jika mengacu pada himbauan pemerintah pusat protocol kesehatan Covid-19 hanya ada 3 macam yaitu menggunakan masker, mencuci tangan dengan sabun dan menjaga jarak. Berdasarkan anjuran pemerintah tersebut pada dasarnya melakukan ibadah berjamaah tidak menjadi masalah yang penting mematuhi protocol kesehatan yang telah ditetapkan. Diskriminasi terhadap pengunjung di luar komunitas seharusnya tidak dilakukan. Berdasarkan hasil wawancara terhadap salah seorang warga menjelang bulan Puasa beberapa waktu yang lalu telah keluar peraturan pemerintah daerah yang menghendaki agar segala aktivitas peribadahan dilakukan di rumah masing-masing. Hal ini menimbulkan reaksi keras dari berbagai kelompok masyarakat. Hingga pada akhirnya dapat dicapai sebuah kesepakatan bahwa beribadah secara berjamaah boleh dilakukan hanya untuk masyarakat di sekitar tempat ibadah tersebut. Hal inilah yang menyebabkan terjadinya diskriminasi terhadap orang di luar komunitas dalam menggunakan sarana ibadah. Jika ditinjau dari segi keadilan keputusan yang diambil warga pada dasarnya melanggar asas keadilan. Fasilitas ibadah adalah sarana umum, setiap orang memiliki hak yang sama untuk beribadah di tempat tersebut. Jika bericara keadilan maka keputusan yang diambil harus berlaku untuk semua. Ada sebagian yang diizinkan beribadah secara berjamaah, sedangkan pada bagian yang lain dilarang. Hal ini menunjukkan adanya 
egoisme kelompok. Kalau tempat ibadah ditutup harusnya ditutup semua agar rantai penyebaran virus benar-benar terputus. Kalau dibuka harus dibuka untuk semua, tidak boleh ada diskriminasi. Karena pada dasarnya yang harus dihindari adalah kerumunan massanya, bukan asal usul jamaahnya. Terlebih lagi bagi musafir, dengan adanya pembatasan ini akan mengalami kendala dalam melakukan ritual ibadahnya. Hal inilah yang dimaksud dengan diskriminasi dalam beribadah.

Diskriminasi yang selanjutnya terjadi selama pandemic adalah diskriminasi dalam bidang sosial. Diskriminasi dalam bidang sosial merupakan bentuk diskriminasi yang paling berbahaya. Hal ini dikarenakan bentuk diskriminasi ini dapat menimbulkan terputusnya ikatan persaudaraan, perpecahan di dalam masyarakat bahkan dapat menimbulkan terjadinya konflik. Salah satu penyebab terjadinya diskriminasi sosial adalah rasa takut yang berlebihan di kalangan masyarakat terhadap Covid19. Akibatnya sering mengabaikan akal sehat dan hati nuraninya sebagai manusia. Berdasarkan hasil pengamatan di masyarakat bentuk-bentuk diskriminasi sosial antara lain: 1) Diskriminasi terhadap orang sakit. Sebelum terjadinya pandemi jika ada saudara atau tetangga yang sakit setiap orang berduyun-duyun untuk menjenguk dan memberikan bantuan sesuai dengan kemampuannya. Namun dengan adanya pandemic fenomena ini jarang terlihat. Bahkan jika ada saudara atau tetangga yang sakit justru akan dijauhi. Terlebih jika telah divonis Corona dapat dipastikan tidak ada yang berani menjenguknya. Tidak hanya dijauhi setiap orang juga enggan memberikan bantuan kepada orang sakit karena takut tertular. Apapun penyakitnya selalu dikaitkan dengan Corona. Terlebih lagi jika gejala yang dimilikinya demam, sesak nafas, dan batuk-batuk. Akibatnya adalah jika ada orang yang merasa kurang sehat tidak berani menampakkan diri karena takut dikucilkan. Bahkan banyak diantara masyarakat yang takut berobat ke rumah sakit. Mereka takut jika sampai di vonis Corona. Menurut penuturan salah satu warga, pada dasarnya yang ditakuti bukanlah penyakitnya tetapi takut dikucilkan oleh masyarakat sekitar. Pengucilan terhadap orang yang terindikasi Covid juga sering terjadi, sehingga menimbulkan ketakutan yang berlebihan di dalam diri setiap orang. Dampak buruknya adalah orang yang benar-benar terpapar dan pernah kotak fisik dengan pasien Covid memilih tidak mau mengaku. Implikasinya penangan terlambat karena virus telah menyebar dan banyak menimbulkan kerugian yang fatal. Hal ini tidak terlepas dari adanya diskriminasi terhadap orang-orang sakit 2) Diskriminasi terhadap orang asing. Orang asing yang dimaksud adalah orang lain di luar komunitas atau orang yang tidak dikenal. Artinya orang asing di sini tidak hanya orang dari luar negeri. Asalkan tidak dikenal dan bukan bagian dari komunitas masyarakat dianggap orang asing. Orang asing seringkali mengalami diskriminasi, salah satu contohnya adalah tidak boleh masuk ke dalam kawasan masyarakat tertentu. Berdasarkan hasil pengamatan dapat ditemukan hampir setiap pintu masuk kampung ada baliho yang bertuliskan orang asing di larang masuk. Implikasinya masyarakat yang ingin berkunjung ke tempat sanak saudara dengan adanya diskriminasi ini mengalami hambatan. Tidak hanya itu pedagang keliling yang biasanya menjajakan barang dagangannya keluar masuk kampung dengan adanya fenomena ini juga merasakan dampaknya. Akibatnya adalah berkurangnya penghasilan untuk memenuhi kebutuhan hidupnya sehari-hari. Diskriminasi terhadap orang asing yang terjadi selama pandemic diwujudkan dengan sikap mencurigai setiap orang asing di luar komunitas, melarang orang asing masuk dalam komunitas. Salah satu dampaknya adalah terbentuknya lingkungan inklusif. 3) Diskriminasi terhadap perantau. Perantau di sini yang dimaksud adalah warga setempat yang bekerja di luar kota. Para perantau ini juga sering mengalami dikriminasi, terlebih lagi jika dia bekerja di daerah yang termasuk kategori zona merah. Diskriminasi kategori ini terjadi tidak lain karena adanya pembatasan sosial skala besar yang dilakukan pemerintah. Adanya himbauan pembatasan sosial berskala besar bagi sebagian masyarakat ditanggapi secara berlebihan. Implikasinya terjadi diskriminasi sosial, bahkan terhadap sanak saudaranya sendiri. Dalam menghadapi pandemic ini terdapat aspek 
kemanusiaan dan prinsip keadilan yang diabaikan. Berdasarkan keterangan salah satu warga siapapun yang datang dari luar kota harus dikarantina terlebih dahulu. Namun demikian setelah dikarantina para perantau juga masih dikucilkan oleh masyarakat sekitarnya. Setiap perantau selalu diawasi dan dicurigai.

Berdasarkan paparan data di atas dapat dipahami bahwa diskriminasi sosial yang terjadi di dalam masyarakat karena kurangnya edukasi yang diberikan kepada masyarakat. Akibatnya adalah timbulnya kepanikan di dalam masyarakat. Selama adanya pandemi media lebih banyak melakukan pemberitaan yang menakutkan. Berdasarkan hasil sebuah penelitian fenomena ini disebut dengan teror informasi. Teror informasi menimbulkan kepanikan, kecemasan dan ketakutan yang luar biasa di kalangan masyarakat (Widodo, 2020c). Hal ini sesuai dengan beberapa penelitian terhadulu yang menyatakan bahwa media sosial sangat berpengaruh dalam membentuk persepsi seseorang dalam menghadapi pandemic Covid 19 dan berpengaruh terhadap kesehatan mental seseorang (Ahmad \& Murad, 2020). Wabah menciptakan rasa takut, dan rasa takut adalah unsur utama bagi perkembangan rasisme dan xenophobia (Devakumar et al., 2020). Rasa takut yang tidak proporsional telah telah menimbulkan sikap diskriminatif dan memengaruhi kelompok-kelompok yang terpinggirkan. Media sosial dalam hal ini harus ikut bertanggungjawab. Penggunaan media sosial dalam penyebaran informasi terutama yang berkaitan dengan Covid-19 intensitasnya sangat sering (Cinelli et al., 2020). Namun demikian kredibilitas informasi yang disebarkan harus diperhatikan. Terdapat salah satu penelitian yang menyatakan bahwa selama pandemic Covid-19 media sosial banyak menyebarkan berita yang salah (Kouzy et al., 2020). Maka dari itu masyarakat harus cermat dalam menanggapi berita yang tersebar dalam media sosial. Kehati-hatian sangat diperlukan dalam menganalisis pemberitaan di media sosial (Llewellyn, 2020). Menanggapi berita di media sosial dengan tidak bijak dapat menimbulkan perilaku yang kurang baik, salah satu diantaranya adalah munculnya diskriminasi sosial.

Menanggapi wabah Covid-19 harus bijak. Tidak perlu berlebihan sehingga menimbulkan diskriminasi sosial. Bangsa Indonesia memiliki ikatan keluarga yang kental. Falsafah hidup bangsa Indonesia mengutamakan kebersamaan dalam setiap permasalahan serta menjunjung tinggi nilai-nilai kemanusiaan (Widodo, Akbar, \& Sujito, 2017). Sejak dini anak-anak selalu dibiasakan dengan pengembangan karakter dan sikap toleransi (Sobri, Nursaptini, Widodo, \& Sutisna, 2019). Adat dan petuah dari generasi terdahulu harus dipertahankan (Sutisna, Komara, Widodo, \& Erfan, 2020). Maka dari itu dalam menyikapi wabah ini tidak seharusnya memunculkan sikap diskriminasi. Pada dasarnya dalam menanggapi wabah Covid-19 diperlukan respon yang cepat dari segenap lapisan masyarakat (Fisher \& Wilder-Smith, 2020). Namun demikian respon yang diberikan harus proporsional serta memperhatikan aspek nilai-nilai kemanusiaan. Diskriminasi sosial yang muncul di tengah pandemic merupakan bentuk pelanggaran terhadap nilai-nilai budaya dan keadilan sosial yang menjadi pandangan hidup bangsa Indonesia. Semangat persatuan dan kestuan harus dijunjung tinggi dalam menghadapi pandemi. Kebersamaan sangat diperlukan, karena seberat apapun permasalahan jika dihadapi bersama akan mudah. Dalam sebuah penelitian disebutkan bahwa sinergitas antara pemerintah dan masyarakat sangat diperlukan dalam melawan wabah Corona (La et al., 2020). Stigma, diskriminasi, dan isolasi sosial perlu disingkirkan dari masyarakat (Singh \& Subedi, 2020). Egoisme pribadi dan kelompok harus dihilangkan.

Terdapat beberapa perbedaan bentuk diskriminasi yang terjadi di Indonesia dengan yang terjadi di luar negeri. Tindakan diskriminasi di luar negeri cenderung rasis. Perlakuan diskriminatif terhadap minoritas Eropa di Eropa adalah contoh kasus yang brutal (Matache \& Bhabha, 2020). Terdapat sentiman anti Roma yang meningkat selama pandemi. Jika di beberapa Negara lain etnis China yang menjadi sasaran maka orang-orang Roma di Eropa 
mengalami nasib yang serupa. Sentimen ras di Indonesia selama pandemi belum ditemukan. Namun demikian diskriminasi yang muncul di Indonesia tidak kalah berbahanya dengan sentimen ras di luar negeri. Diskriminasi yang ada di Indonesia dapat menimbulkan putusnya ikatan persaudaraan. Jika hal ini dibiarkan maka persatuan dan kesatuan bangsa akan terancam. Satu hal yang perlu diwaspadai adalah terbentuknya perilaku kolektif dari masyarakat. Perilaku kolektif yang dimaksud di sini adalah adanya perilaku diskriminasi yang dilakukan oleh seluruh lapisan masyarakat dan telah dianggap sebagai bentuk kewajaran. Hal ini dikarenakan salah satu pembentuk perilaku seseorang adalah adanya pengaruh dari perilaku masyarakat di tempat orang itu berada (Widodo, 2020b). Jika hal ini terus berlanjut maka tatanan sosial akan menjadi rusak. Maka dari itu setiap elemen masyarakat harus bekerjasama dalam menanggulangi bencana ini. Peran pemerintah sangat penting, terutama dalam melahirkan kebijakan-kebijakan yang adil sehingga tidak ada golongan yang merasa terdiskriminasi.

\section{SIMPULAN}

Berdasarkan hasil penelitian dapat diketahui bahwa diskriminasi terjadi karena adanya sikap takut berlebihan yang dialami masyarakat. Akibatnya masyarakat cenderung over protektif. Terdapat beberapa bentuk diskriminasi baru selama pandemic covid-19 antara lain diskriminasi kebijakan, diskriminasi peribadahan dan diskriminasi sosial. Diskriminasi kebijakan dapat terlihat dari adanya perbedaan perlakuan dan peraturan terhadap bidangbidang yang berpotensi menjadi tempat penyebaran wabah. Diskriminasi peribadahan terlihat dari adanya pembatasan penggunaan tempat ibadah bagi masyarakat di luar komunitas. Diskriminasi sosial diwujudkan dengan adanya sikap saling mencurigai, pengucilan terhadap para perantau, pengucilan terhadap orang yang sakit, antipati terhadap orang asing dan terbentuknya lingkungan inklusif.

\section{SARAN}

Berdasarkan hasil penelitian terdapat berbagai saran yang diberikan kepada berbagai pihak: 1) Pemerintah seharusnya membuat skala prioritas dan langkah-langkah konkrit dalam menangani Covid-19 dengan memperhatikan aspek keadilan dan kemanusiaan, 2) kepada masyarakat seharusnya menyikapi pandemic dengan bijak. Jangan takut berlebihan sehingga menimbulkan diskriminasi, tetapi juga harus tetap waspada mengingat Covid-19 adalah jenis virus yang sangat berbahaya.

\section{DAFTAR PUSTAKA}

Ahmad, A. R., \& Murad, H. R. (2020). The Impact of Social Media on Panic During the COVID-19 Pandemic in Iraqi Kurdistan: Online Questionnaire Study. Journal of Medical Internet Research, 22(5), e19556. https://doi.org/10.2196/19556

Andersen, M. (2020). Early Evidence on Social Distancing in Response to COVID-19 in the United States. SSRN Electronic Journal. https://doi.org/10.2139/ssrn.3569368

Bavel, J. J. Van, Baicker, K., Boggio, P. S., Capraro, V., Cichocka, A., Cikara, M., ... Willer, R. (2020). Using social and behavioural science to support COVID-19 pandemic response. Nature Human Behaviour, 1-12. https://doi.org/10.1038/s41562-020-0884-z

Bledsoe, T. A., Jokela, J. A., Deep, N. N., \& Snyder Sulmasy, L. (2020). Universal Do-NotResuscitate Orders, Social Worth, and Life-Years: Opposing Discriminatory Approaches to the Allocation of Resources During the COVID-19 Pandemic and Other Health System Catastrophes. Annals of Internal Medicine, M20-1862. https://doi.org/10.7326/M20-1862

Bo, H.-X., Li, W., Yang, Y., Wang, Y., Zhang, Q., Cheung, T., ... Xiang, Y.-T. (2020). Posttraumatic stress symptoms and attitude toward crisis mental health services among 
clinically stable patients with COVID-19 in China. Psychological Medicine, 1-2. https://doi.org/10.1017/S0033291720000999

Chung- Ying, L. (2020). Social Reaction toward the 2019 Novel Coronavirus (COVID- 19)

With. Social Health and Behavior, (March), 2-3. https://doi.org/10.4103/SHB.SHB

Cinelli, M., Quattrociocchi, W., Galeazzi, A., Valensise, C. M., Brugnoli, E., Schmidt, A. L., ... Scala, A. (2020). The COVID-19 Social Media Infodemic. 1-18. Retrieved from http://arxiv.org/abs/2003.05004

Depoux, A., Martin, S., Karafillakis, E., Preet, R., \& Wilder-Smith, A. (2020). The pandemic of social media panic travels faster than the COVID-19 outbreak. Journal of Travel Medicine, Maret, 368. https://doi.org/10.1093/jtm/taaa031

Devakumar, D., Shannon, G., Bhopal, S. S., \& Abubakar, I. (2020). Racism and discrimination in COVID-19 responses. The Lancet, 395(10231), 1194. https://doi.org/10.1016/S0140-6736(20)30792-3

Fisher, D., \& Wilder-Smith, A. (2020). The global community needs to swiftly ramp up the response to contain COVID-19. The Lancet, 395(10230), 1109-1110. https://doi.org/10.1016/S0140-6736(20)30679-6

He, J., He, L., Zhou, W., Nie, X., \& He, M. (2020). Discrimination and Social Exclusion in the Outbreak of COVID-19. International Journal of Environmental Research and Public Health, 17(8), 2933. https://doi.org/10.3390/ijerph17082933

Indraswati, D., Widodo, A., Rahmatih, A. N., Maulyda, M. A., \& Erfan, M. (2020). Implementasi Sekolah Ramah Anak dan Keluarga di SDN 2 Hegarsari, SDN Kaligintung, dan SDN 1 Sangkawana. JKKP: Jurnal Kesejahteraan Keluarga Dan Pendidikan, 7(1), 51-62.

Kantamneni, N. (2020). The impact of the COVID-19 pandemic on marginalized populations in the United States: A research agenda. Journal of Vocational Behavior, 119, 103439. https://doi.org/10.1016/j.jvb.2020.103439

Kouzy, R., Abi Jaoude, J., Kraitem, A., El Alam, M. B., Karam, B., Adib, E., ... Baddour, K. (2020). Coronavirus Goes Viral: Quantifying the COVID-19 Misinformation Epidemic on Twitter. Cureus, 12(3), 1-9. https://doi.org/10.7759/cureus.7255

La, V. P., Pham, T. H., Ho, M. T., Nguyen, M. H., Nguyen, K. L. P., Vuong, T. T., ... Vuong, Q. H. (2020). Policy response, social media and science journalism for the sustainability of the public health system amid the COVID-19 outbreak: The vietnam lessons. Sustainability (Switzerland), 12(7). https://doi.org/10.3390/su12072931

Lippi, G., \& Plebani, M. (2020). Laboratory abnormalities in patients with COVID-2019 infection. Clinical Chemistry and Laboratory Medicine (CCLM), February 2, 1-4. https://doi.org/10.1515/cclm-2020-0198

Llewellyn, S. (2020). Covid-19: how to be careful with trust and expertise on social media. BMJ, 368(March), m1160. https://doi.org/10.1136/bmj.m1160

Marston, H. R., Musselwhite, C., \& Hadley, R. (2020). COVID-19 vs Social Isolation: the Impact Technology can have on Communities, Social Connections and Citizens. Ageing Issues, (2019), 1-6. Retrieved from https://ageingissues.wordpress.com/2020/03/18/covid-19-vs-social-isolation-the-impacttechnology-can-have-on-communities-social-connections-

Matache, M., \& Bhabha, J. (2020). Anti-Roma Racism is Spiraling during COVID-19 Pandemic. Health and Human Rights, 22(1), 379-382. Retrieved from http://www.ncbi.nlm.nih.gov/pubmed/32669824

Singh, R., \& Subedi, M. (2020). COVID-19 and stigma: Social discrimination towards frontline healthcare providers and COVID-19 recovered patients in Nepal. Asian Journal of Psychiatry, 53, 102222. https://doi.org/10.1016/j.ajp.2020.102222

Sobri, M., Nursaptini, N., Widodo, A., \& Sutisna, D. (2019). Pembentukan karakter disiplin 
siswa melalui kultur sekolah. Harmoni Sosial: Jurnal Pendidikan IPS, 6(1), 61-71. https://doi.org/10.21831/hsjpi.v6i1.26912

Sutisna, D., Komara, E., Widodo, A., \& Erfan, M. (2020). Actualization Of Wuku Taun Tradition In The Midst Of Modernization ( A Case Study To The Peoples Of Cikondang Traditional Village In Pangalengan, Bandung ). Civic-Culture: Jurnal Ilmu Pendidikan PKn Dan Sosial Budaya, 4(2), 350-367. Retrieved from http://jurnal.stkippgribkl.ac.id/index.php/CC/article/view/319/305

Watkins, J. (2020). Preventing a covid-19 pandemic. The BMJ, 368(February), 1-2. https://doi.org/10.1136/bmj.m810

Widodo, A. (2020a). Nilai Budaya Ritual Perang Topat Sebagai Sumber Pembelajaran IPS Berbasis Kearifan Lokal di Sekolah Dasar. Gulawentah:Jurnal Studi Sosial, 5(1), 1. https://doi.org/10.25273/gulawentah.v5i1.6359

Widodo, A. (2020b). Penyimpangan Perilaku Sosial Ditinjau dari Teori Kelekatan Bowlby (Studi Kasus Terhadap Anak Tenaga Kerja Wanita di Lombok Barat). ENTITA: Jurnal Pendidikan Ilmu Pengetahuan Sosial Dan Ilmu-Ilmu Sosial, 2(1), 35-50. https://doi.org/http://dx.doi.org/10.19105/ejpis.v1i2.3187

Widodo, A. (2020c). Teror Informasi dan Perilaku Mahasiswa Dalam Penggunaan Media Sosial Selama Pandemi Covid-19. Civic-Culture: Jurnal Ilmu Pendidikan PKN Dan Sosial Budaya, 4(1), 45-58. Retrieved from http://jurnal.stkippgribkl.ac.id/index.php/CC/article/view/364

Widodo, A., Akbar, S., \& Sujito, S. (2017). Analisis nilai-nilai falsafah Jawa dalam buku pitutur luhur budaya Jawa karya Gunawan Sumodiningrat sebagai sumber belajar pada pembelajaran IPS. Jurnal Penelitian Dan Pendidikan IPS (JPPI), 11(2), 152-179. Retrieved

from http://ejournal.unikama.ac.id/index.php/JPPI/article/download/1887/1489/

Zhai, Y., \& Du, X. (2020). Mental health care for international Chinese students affected by the COVID-19 outbreak. The Lancet Psychiatry, 7(4), e22. https://doi.org/10.1016/S2215-0366(20)30089-4 